\title{
The Perceptions Of Secondary School 9th, 10th And 11th Grade Students With Regard To History And History Consciousness
}

\author{
Ayla ARSEVEN ${ }^{1}$, F. Mehmet DERVIŞOĞLU ${ }^{2}$, Cengizhan ULUDA $\breve{G}^{3}$
}

\author{
Summary
}

\section{INTRODUCTION}

In the Western languages, the words history, historia etc. is derived from the Greek word "istoria" and it means "researching and examining events one by one. The Arabic equivalent of the word history is usture refers to the concepts of myth or mythology. The Holy book Quran give information about Ad and Semud tribes so that next generations understand the reason why these tribes were destroyed and draw a lesson from this. It is possible to develop two perspectives in the West and East with regard to the meanings attributed to history and what history means. The first is that history is regarded as events that took place in the past and ignoring it. The second is to try to understand the reason of historical events and interpret history. In this sense, history does not only consist of past events. It helps us to understand today and think about the future (Uçar 1997:15).

\section{METHODOLOGY}

\section{Study Model}

The study is conducted with a phenomenological design, which is one of the qualitative research methods. In this study, interview method as one of the qualitative research methods.

\section{Study Group}

The study group is composed of 309 th, 10th and 11th grade students attending a state high school which was ranking at the middle level in terms of its students success in university entrance exam. Focus group interviews were made with the students. In choosing the study group, maximum sampling method was used. The students were interviewed in groups of 5 and a total of 30 students were interviewed. Each interview took 25 minutes on average and the interviews were completed in six sessions.

\section{Data Collection Tools}

In this study, a semi-structured "Student Interview Form", composed of 10 questions, 6 alternative questions and 21 probes, was developed after relevant literature was reviewed by the researcher.

\section{Data Analysis}

For the analysis of the data collected via the "Student Interview Form" which was developed based on research questions, content analysis was used. For the analysis, first of all The interviews were recorded and transcribed. The students were assigned numbers between 1 and 30 by indicating their grades and genders (such as 9,MS1; 10,FS2; 11,FS9). Direct quotations from students were given with participant forms.

\footnotetext{
1 Assist. Prof., Cumhuriyet University, Faculty of Education, aylaarseven2004@yahoo.com

${ }^{2}$ Assoc. Prof., Cumhuriyet University, Faculty of Education, dervisoglu@cumhuriyet.edu.tr

${ }^{3}$ Ministry of National Education
} 
Cumhuriyet International Journal of Education-CIJE

e-ISSN: 2147-1606

Vol 4 (1), 2015, $65-82$

\section{FINDINGS}

As a results of interviews with students, data were represented under two headings: "students' perceptions with regard to history", and "the factors that affect students" development of history consciousness".

\section{Students perceptions and ideas with regard to history}

The students' perceptions with regard to history, categories such as the concept of history, history related media, Literature and Art Products, perception of history, the importance of history and the usefulness of history for individual and society emerged. Students who did not define history with one sentence mostly emphasized past and wars or agreements. With regard to this issue, students coded as 9MS1 and 11FS1 used the following statements.

"History is the events in the past." 9, MS1

"The past of a nation is history." 11,FS1

When the answers students gave to the questions "Which one of the areas that include historical facts and themes do you like most? Why?", it was seen that wise sayings, movies, poems, anthems, stories, documentaries, books, discussion programs on TV come to the fore. The fact that students especially like poems, songs, anthems, legends and stories can be attributed to the fact that their interest are drawn to the areas where they feel intense emotions. Besides, students think movies, documentaries and discussion programs are catchier compared to books and they are liked more as they share new information.

\section{The factors that affect students history consciousness}

The factors that influence students' history consciousness have been determined to be as the sources they learn history from, perception of self-efficacy with regard to historical knowledge, historical figures and events.

When the responds of the students provided for the questions "What kind of sources do you learn history from?" are examined, it was found that students mostly learnt history from their teachers. Besides, it is also possible to say that visual narrations like movies, documentaries, and video are important sources to learn history. We can count textbooks and the Internet/social media among the sources students learn history form. It is interesting to note that some students learn by visiting historical places and some show interest in what their elder family members or other adults tell them. Students' views with regard to this situation is given below:

"Generally we learn history from what our teachers tell us at school. We remember the things we learn more visually are catchier. Movies and theaters plays (related to historical events) are the ones most remembered." 10, MS1

\section{DISCUSSION AND SUGGESTIONS}

In this study, it was seen that students' historical consciousness and ideas do not go beyond bookish definitions. It was seen that while the students defined history with the concepts "past and event", they were not aware of its importance for today and future. The importance of history for the future is not mentioned apart from a few slogan like sentences. While students find the presentation of document based information boring, they expressed that they liked activities like poems, songs, anthems that appeal to feelings. Most of the students stated that they learnt history textbooks, teachers, movies, and the Internet. This study reveals the importance of history lessons and teachers in learning history, which 
Cumhuriyet International Journal of Education-CIJE

e-ISSN: $2147-1606$

Vol 4 (1), 2015, 65 - 82

indicates that history taught at school is very important. Therefore, a few amendments are necessary in secondary education history syllabus. 